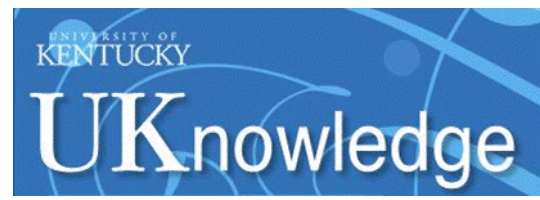

University of Kentucky

UKnowledge

Preventive Medicine and Environmental Health

Presentations

Preventive Medicine and Environmental Health

January 2012

\title{
Public Health Services and Systems Research
}

\author{
F. Douglas Scutchfield MD \\ University of Kentucky, scutch@uky.edu
}

Follow this and additional works at: https://uknowledge.uky.edu/pmeh_present

Part of the Education Commons, Life Sciences Commons, Medicine and Health Sciences Commons, and the Social and Behavioral Sciences Commons

Right click to open a feedback form in a new tab to let us know how this document benefits you.

\section{Repository Citation}

Scutchfield, F. Douglas MD, "Public Health Services and Systems Research" (2012). Preventive Medicine and Environmental Health Presentations. 12.

https://uknowledge.uky.edu/pmeh_present/12

This Presentation is brought to you for free and open access by the Preventive Medicine and Environmental Health at UKnowledge. It has been accepted for inclusion in Preventive Medicine and Environmental Health Presentations by an authorized administrator of UKnowledge. For more information, please contact UKnowledge@lsv.uky.edu. 


\section{Public Health Services \& Systems Research}

January 19, 2012

PHLR Annual Meeting

New Orleans, LA

F. Douglas Scutchfield, M.D.

Director

University of Kentucky

National Coordinating Center for

Public Health Systems \& Services Research 


\section{Definition}

Public Health Services and Systems Research:

A "field of study that examines the organization,

financing, and delivery of public health services

within communities and the impact of those

services on public health". 
Social, Political, Economic forces operating in the overall society (e.g. National economy)

Extent of Demand and need for public health services within the population

Social values and preferences for products of public health systems (e.g. clean water)

External forces such as: Medical delivery systems, Technological advances, Nature of federal-state-local relationships
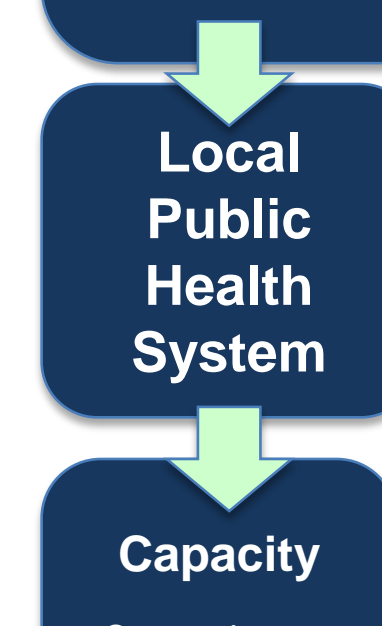

System Inputs:

Workforce

Facilities

Technology

Organizational

relationships

\section{PHSSR MISSION AND PURPOSE}

Goals and how they are to be implemented

Performance of the core functions of assessment, policy development, and assurance

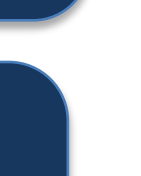

Funding

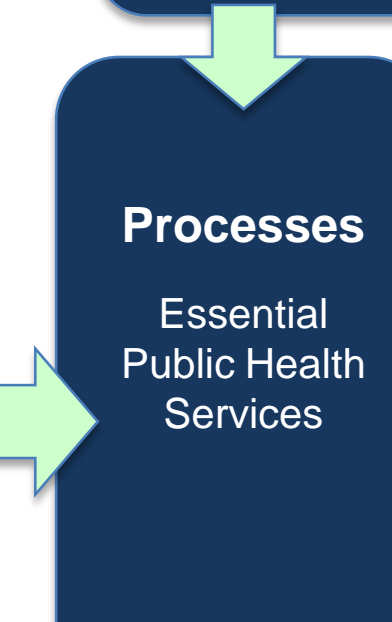

Outputs

Programs and

Services

consistent with

mandates and

community

priorities
Process Outcomes

Improved organizational performance

Improved program performance

\section{Community} Health Outcomes

Improved Health Practices, Environment, Life Styles

Improved Morbidity and Mortality Rates Improved Health Status 


\section{PHSSR Research Agenda}

National Coordinating Center for PUSSR

\section{Sections:}

-Finance

-Organization and Structure

-Workforce

-Technology, Data and Methods

\section{Website:}

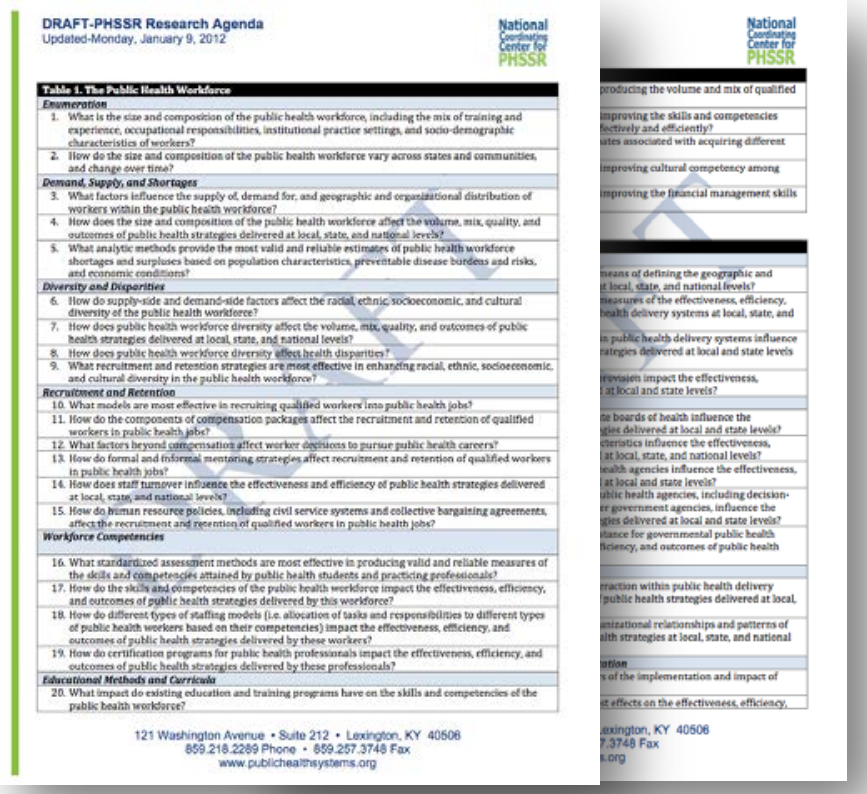

-http://www.publichealthsystems.org/cphssr/Research/PHSSR Research Agenda 


\section{PHLR/PHSSR Agenda}

1) the structural role of law in shaping the organization, powers, prerogatives, duties and limitations of public health agencies, and thereby their functioning and ultimately their impact on public health ("infrastructure");

2) the way that public health system characteristics influence the implementation of interventional public health laws ("implementation"); and

3) the individual and system characteristics that influence the ability of public health systems and their community partners to develop and secure enactment of legal initiatives to advance public health ("innovation"). 


\section{Three Questions for PHLR/PHSSR}

1) What is the relationship between statutory architecture and language and the outputs and outcomes of public health systems?

2) What are the structural/operational determinants of implementation of law by health agencies?

3) What individual and system characteristics influence the ability of public health systems and their community partners to develop and secure enactment of legal initiatives to advance public health? 
For more information contact:

F. Douglas Scutchfield, M.D.

National

scutch@uky.edu

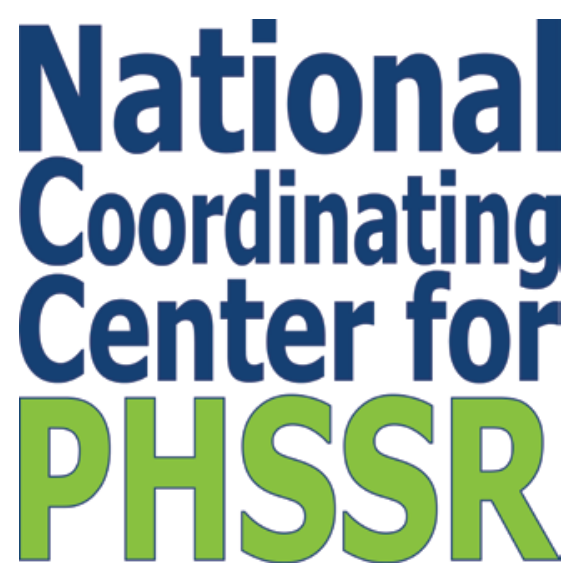

111 Washington Avenue, Suite 212

Lexington, KY 40517

$$
\text { 859-257-5678 }
$$

www.publichealthsystems.org 